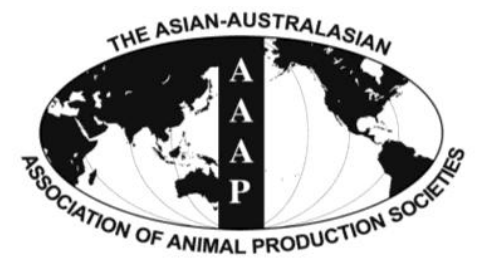

\title{
Management of Reproduction on Small, Medium and Large Rabbit Farms: A Review
}

\author{
Zs. Szendrö*, K. Szendrő and A. Dalle Zotte ${ }^{1}$ \\ Kaposvár University, Kaposvár, 7400, Hungary
}

\begin{abstract}
One of the main goals of small, medium and large farms is to improve the reproductive performance of rabbit does. Stocks of lower productivity can be improved by crossing with intensive breeds. A better nutritional status of both foetuses and suckling kits has a positive effect on their later productivity. Overfeeding young females before first mating can lead to conditions of fattiness. Using restricted feeding or higher fibre content in the feed and changing it for a higher level ad libitum feeding about one week prior to first mating leads to longer lifespan and higher productive level. Intensive reproductive rhythm creates a negative energy balance in does : they are unable to consume enough feed (energy) for the nutritional requirements of foetus and lactation, and therefore lose most of their fat reserves. Furthermore, primiparous does also expend energy because they are still growing. Under intensive conditions, the 42-d reproductive rhythm (re-mating 11 days after parturition) is recommended. Under extensive conditions, the 18 or $25-\mathrm{d}$ mating interval with 35 to $42-\mathrm{d}$ weaning could be suitable. On small farms, natural mating is favoured; on large farms AI is commonly employed. The main advantage of AI is the all-in, all-out system. Hormonal (PMSG) treatment is used with AI to increase receptivity on d 11. Frequent and high level PMSG use can lead to higher anti-PMSG antibody rates. Lower level (max. 20 IU) and less frequent PMSG injection or non-hormonal alternative methods (short dam-litter separation, changing nursing method or lighting programs) are recommended for this reason. (Key Words: Rabbit Does, Reproductive Rhythm, Energy Balance, Hormonal Treatment, Biostimulation, Farm Size)
\end{abstract}

\section{INTRODUCTION}

Rabbit farms can be classified as small, medium, and large. Their owners usually started out with just a few does and a stock of growing rabbits for their own consumption (Lebas et al., 1986). When rabbit meat became available at butchers, rabbit farms started increasing in size and selling animals. Not only the number of does increased, but also breeds, housing conditions, feeding, and management techniques were developed accordingly.

The owners of backyard stocks in Europe are only moderately interested in know-how. Most follow family tradition and keep rabbits in the same way as their parents or grandparents. Owners of medium-sized farms are interesting in learning more and using this knowledge to the best of their limited financial resources. Farmers with a

\footnotetext{
* Corresponding Author: Zs. Szendrö. Tel: +36-82-505-800, Fax: +36-82-320-175, E-mail: szendro.zsolt@ke.hu

1 Department of Animal Medicine, Production and Health, University of Padova, Agripolis, Viale dell'Università, 16, 35020, Legnaro (PD), Italy.

Submitted Jan. 6, 2012; Accepted Feb. 7, 2012; Revised Feb. 22, 2012
}

large number of good quality animals (kept in closed buildings, modern cages, and fed with pellets, etc.) are those most interested in expanding their knowledge in order to increase efficiency and productivity while cutting costs for higher income. On large farms, profit per animal or profit per cage decrease continuously, and so farmers increase farm size for higher benefits. The survey report by Hanzhong (2008) describes the emerging Chinese rabbit industry and its high economic value, notable market prospects, and unique advantages. The Chinese say that if a family has several rabbits, it will not lack in oil, salt and vinegar, if a family has one hundred rabbits, it will not lack clothes and pants, and if a family has one thousand rabbits, it will not lack a building.

Scientific papers and reviews mainly deal with issues of intensive farming. Industrial rabbit production is concentrated mainly in some European countries (e.g. Italy, France, Spain, Hungary and Belgium), while medium and small sized farms are representative of the rest of the world, from South-America to Asia. Broadening scientific knowledge in such farms is essential for their development. For this reason, management of reproduction on each farm 
size is also emphasized in the review.

This paper deals with a number of practical aspects of the work on small, medium, and large farms. The main topics are:

- breeds and selection

- rearing future does

- mating

- artificial insemination

- re-mating interval

- palpation of pregnancy

- suckling mortality

- teat number

- seasonal effect

Apart from artificial insemination, most of these topics apply equally well to all farms.

\section{RESULTS AND DISCUSSION}

\section{Breeds and selection}

Breeds used for meat production can be categorized as

- native (local) breeds,

- coloured (extensive) breeds,

- intensive breeds, such as New Zealand or Californian,

- synthetic breeds,

- hybrids.

Certain native breeds are used primarily in hot climate countries or specific districts in other countries. Even if their reproductive performance is low, they are well-adapted to the local environment and highly resistant (hot climate, low nutritional level, local feedstuffs) to keeping conditions (Lukefahr, 1992). For backyard rabbit husbandry or home meat production, breed choice does not assume critical importance (Cheeke et al., 1986). Inexpensiveness and resistance may be the most important characteristics.

Coloured breeds are kept in numerous countries to produce meat for own consumption or special markets. Some coloured breeds are used in Europe in organic farming or alternative systems. Their productivity is between those of native and intensive breeds. Their reproductive ability is good enough, even under weak conditions, and this makes them common at small farms.

Intensive breeds are suitable for medium and large farms due to their good reproductive and productive performance. They are used for their good maternal ability and steady litter size (Zhiqiang and Xiaoyan, 2008). New Zealand White and Californian are bred throughout the world as leading commercial breeds (Cheeke et al., 1986).

Synthetic breeds originated from the crossing of two or more intensive breeds to introduce higher reproductive and productive characteristics and adapt to different environmental conditions or consumer preferences in a given country. Californian, the best known synthetic breed, originated from Himalayan, Chinchilla rabbit and New Zealand White crosses (Cheeke et al., 1986). Most synthetic breeds are popular in the country where they are bred.

There are other ways to increase reproductive performance.

The easiest and quickest way is to cross existing stock with intensive breeds (lines). Note that imported breeds must be chosen carefully. The best choices to improve reproductive or productive performances might be New Zealand White, Californian, or similar types of mediumsized breeds.

Another well-known method is crossbreeding. Several experiments have been carried out in which the heterosis of crossbred populations has been proven in reproductive traits (e.g. litter size) (Brun and Saleil, 1994; Jensen et al., 1996; Nofal et al., 1996; Das et al., 1997; Brun et al., 1998; Khalil et al., 2002; Brun and Baselga, 2005; Szendrö et al., 2007a).

Another crossbreeding system is rotational crossing, in which purebred males are mated with crossbreed females. Each purebred sire breed is alternated (rotated) between successive generations (Cheeke et al., 1986):

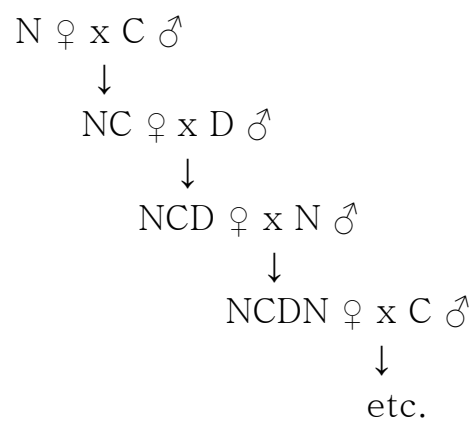

( $\mathrm{N}=$ New Zealand, $\mathrm{C}=$ Californian, $\mathrm{D}=$ Danish)

Selection: Garreau et al. (2004) and Khalil and Al-Saef (2008) summarized selection criteria, technique, and direct and correlated genetic responses in maternal lines. In most cases, the litter size at birth or at weaning is adopted for selection criteria and selection is based on the BLUP procedure. Some lines have been selected for over 30 generations. The heritability of the litter size is very low (sometimes under 0.1), therefore the selection responses per generation are also low (0.03 to 0.18). In some cases, new criteria (mortality, longevity or genetic variability) are built into the selection programs. The main purpose of selecting maternal lines is to produce crossbred (parents) does for a hybrid program. The (maternal) heterosis effect could be high $(15 \%$ and $16 \%$ in litter size alive and weaned, Brun et al., 1992). The mostly widely-known hybrids (Hyplus, Hycole, Hyla and Zika) have two maternal lines and one 
terminal line.

\section{Rearing future does}

The elements that affect reproductive performance are mainly examined during the breeding period. However, some factors before first mating may also influence life performance. One of the most important effects might be nutritional status (foetuses, suckling kits, and young females) before breeding.

Birth weight (nutritional status of foetuses) is determined mainly by litter size and the position of foetuses in the uterine horns (Lebas, 1982; Pálos et al., 1996; Poigner et al., 2000; Szendrő and Maertens, 2001). Several papers published on humans indicate that birth weight has long-term effects on health and lifespan (Barker et al., 1989; Doblhammer and Vaupel, 2001). Although several studies on rodents are also available (Pond and $\mathrm{Wu}, 1981$; Langley-Evans and Sculley, 2006), we have not yet found any studies on farm animals. We assume the same correlation between birth weight and adult performance in these animals, and therefore the selection of animals of larger birth weight might be suggested for better reproductive performance.

The nutritional (milk) supply of kits also has a longterm effect. Babile et al. (1982) reared kits in small and larger litters. The does in litters with 5 kits kindled and reared larger litters than those born in litters with 11 kits. Our results (Szendrö et al., 1989) indicate that the size of the litter in which kits were born and nursed affected their performance in adult age as well. Rommers et al. (2001) observed that does taken from large litters (12) had low productivity. When Gyovai et al. (2004a, 2004b) nursed kits with one or two does, the results showed a significant difference in milk consumption. Nursing kits with two does has a positive effect on their adult performance, as well.

Better nutrient supply during suckling age could result in better adult performance. The main reason for this might be the better condition (higher body weight) of the does. The ratio of fat to muscle tissue measured by computer tomography at the age of first mating was higher in the group nursed by two does than in the group nursed by one (Szendrő et al., 2006a).

Restricted feeding: Feed restriction increases the length of life of rats and other laboratory rodents considerably (Masoro et al., 1980). Using a slimming diet against obesity is commonly practiced around the world. People consume less than their appetite on such diets. After the diet ends, their food consumption might be higher and digestibility of nutrients became better. Consequently several weeks or months later, they might even be fatter than at the start of the slimming program (MacCuish et al., 1968).

However, this method may offer certain advantages in animal (rabbit) nutrition. When feed intake is reduced, rabbits are leaner (not only fat deposits but also total muscle lipid content is lower) (Gondret et al., 2000). The rabbits reach optimal weight for first mating one or two weeks later than usual, and thus are more developed physiologically. When restriction ends, they begin consuming more feed. Nulliparous does must grow by about 0.3 to $0.5 \mathrm{~kg}$ until adult weight; furthermore; litter (foetus) weight at birth is around $0.5 \mathrm{~kg}$ and the does also produce around 4 to $5 \mathrm{~kg}$ of milk ( 0 to $28 \mathrm{~d}$ of lactation). In order to achieve such high performance, they have to mobilise their fat deposits because of limited feeding capacity. Terminating feed restriction some days prior to first mating is similar to flushing (with energy and protein intake increasing suddenly), and feed consumption is higher for a longer time. Digestibility of nutrients is better as well.

This theory has been proven in some experiments. When feed restriction ended, although body weight was lower than in the ad libitum group (Hartmann and Petersen, 1997; Gyovai et al., 2004b) due to their higher consumption at the time of the first parturition, their body weight was higher than in the group reared with ad libitum feeding (Gyovai et al., 2004b). Rabbits fed restricted diets can also digest nutrients (DM, OM, DF) with higher efficiency (Di Meo et al., 2007).

Does reared with restricted feeding may provide better performance. Eiben et al. (2001) observed slightly higher conception rate, larger litter size, and higher milk production (litter weight), especially when a $9 \mathrm{~h} / \mathrm{d}$ feeding duration was applied until the rabbits reached 3.4 to $3.5 \mathrm{~kg}$ body weight. In an experiment by Hartmann and Petersen (1997), higher milk yield (litter weight gain) was ascribed to a $68.5 \%$ restriction of the ad libitum level (1st litter: +42 g, 2nd litter: +206 g, 3rd litter: +267 g). In contrary, Gyovai (2006) did not find any advantages in the restricted group. By combining the effects of nursing doe number (1 or 2) with young doe feeding regime (ad libitum or restricted), the best lifetime production was observed in the group with high milk consumption and restricted feeding until 3 days prior to first mating (group TR). When compared to the traditional method (nursing by one doe fed ad libitum), the group TR produced more rabbits born total and alive by 14 and $16 \%$, respectively (Szendrö et al., 2006a).

The productive performance of primiparous, restricted fed does (R) may be low. In most cases, the conception rate of first mated does was significantly lower than in the $a d$ libitum fed group (A). In an experiment of Gyovai (2006), the results were $59.5 \%$ and $83.3 \%$ in groups $\mathrm{R}$ and $\mathrm{A}$, respectively. Larger differences were found if they were mated first at 15.5 than at 18.5 wks of age (Gyovai, 2006). Matics et al. (2008) compared the reproductive performance of middle (M) and large (L) adult body weight genotypes fed restricted diets and mated first at 19.5 wks of age (R19) or fed ad libitum and mated at 15.5 wks of age (A15). The 
conception rate of nulliparous $\mathrm{M}$ does was lower (8.8\%) than that of the $\mathrm{L}$ does $(15.5 \%)$. These results show that larger body breeds reach the condition for breeding at an older age than middle bodyweight genotypes. Eiben et al. (2001) inseminated does at the same weight, thus the rabbits in the restricted group were older. In this case, the control group had a lower conception rate than the restricted group. Matics et al. (2008) mated the restricted group at an older age (19.5 wk) than the ad libitum (15.5 wks) group. In this case, the restricted group showed a higher conception rate.

The use of feed restriction poses the following questions:

- What is the best level of restriction?

- Which method is better: restricting the daily ratio or the daily eating time?

- What is the best age for first mating?

- How many days prior to first mating must restricted feeding be changed to ad libitum?

Without knowing the exact answers, setting restriction to 80 to $85 \%$ of the ad libitum consumption, finishing the restriction 7 to 8 days prior to first mating, and then mating does at 17 to 18 wks of age might be suggested.

Fibrous diet: Not only restriction, but also ad libitum feeding with a fibrous diet may serve the purpose. It is a good way to stimulate feed intake, because it increases the weight and capacity of the digestive tract. Pascual et al. (2002) fed a $21.2 \%$ crude fibre (96\% alfalfa hay) to young female rabbits $(\mathrm{F})$. In the control group, the crude fibre and alfalfa hay contents were 14.4 and $48 \%$, respectively $(\mathrm{C}=$ similar to a commercial diet). This pellet was fed ad libitum until their weight reached $3 \mathrm{~kg}$ and $150 \mathrm{~g} / \mathrm{d}$ afterwards. Digestible energy was 11 and $8 \mathrm{MJ} / \mathrm{kg} \mathrm{DM}$, respectively. Feed (DM) intake of young females in group $\mathrm{F}$ was significantly higher than in group $\mathrm{C}$, but due to its low nutritional value their live weight was lower. After the first parturition, both groups consumed the same commercial pellet ad libitum. At the time of parturition and weaning, there was no significant difference in the doe body weight even if does in group $\mathrm{F}$ consumed more feed during lactation and their milk production was also higher. In an experiment by Nizza et al. (1997), young female rabbits consumed pellets with high (F) or normal (C) crude fiber content (F: 22.8 and 18.0\% DM) with DE 10.2 and 11.2 $\mathrm{MJ} / \mathrm{kg}$ DM. Does in group F consumed more feed during lactation, and their litter size and litter weight were higher than those of the group C does. Xiccato et al. (1999) also obtained better results in group $\mathrm{F}$, but with insignificant differences.

The results suggest that rearing future reproductive does with a fibrous diet until first mating is easy to manage and provides an effect similar to restricted feeding. Rabbits consume more feed at younger age and the weight of their digestive tract increases. Changing the pellet at first mating (or some days before mating) their appetite increases and several reproductive parameters and overall condition improves as a result.

\section{Mating}

Natural mating is widespread on small and medium farms and suitable with less than 100 does.

Does must be inserted in the buck's cage. The male "lives" in his territory, does not need to spend time investigating, and therefore the mating process is faster. Inspecting the vulva before mating is recommended. Does are in heat when their vulva is red or slightly violet and turgid (Maertens, 1998; Szendrő et al., 2006b). Maertens et al. (1983) showed the relation between vulva colour and certain reproductive traits (the conception rate and the litter size are higher).

After mating, the LH and FSH peak is observed. Ovulation occurs around 10 to $12 \mathrm{~h}$ after mating. At the same time, the sperm makes its way to the fertilization area (ampule). The ova and sperms cells meet at the optimal time for fertilization and are fertile for 6 to 8 and $4 \mathrm{~h}$ respectively.

Some authors suggest mating in both the morning and afternoon in the belief that the successful meeting of sperm and egg at the right time is more certain in this way. Our previous results suggest that the best way is to mate the does twice with two bucks immediately one after the other. Similar results were achieved when does were left in bucks' cages for $2 \mathrm{~h}$ after first mating (Szendrö and Tag-el-Den, 1987). After mating, the service acceptance rate declines. When the duration between two matings was $0,2,4,6,8$ or $24 \mathrm{~h}$, the ratio of unsuccessful second matings was $0,5,7$, 16, 19 and 39\%, respectively (Szendrő and Tag-el-Den, 1987). In the last group, no kits were originated by the second buck. Beyer and Rivaud (1969) observed a sharp decrease in sexual activity from 20 to $24 \mathrm{~h}$ after coitus.

\section{Artificial insemination}

Artificial insemination (AI) is widely used at large farms in Europe. It has five steps:

- collecting semen from the bucks,

- examining the semen visually and microscopically,

- dilution of semen 10 to 20 times if its quality is good,

- inseminating does by pipette,

- injecting GnRH analogue into the hind leg muscle at the moment of insemination.

One of the main advantages of $\mathrm{AI}$ is the possibility to inseminate hundreds or thousands of does the same day. Depending on farm management, either all the does are inseminated on the same day or the stock is halved or 
divided into more groups.

AI also permits the advantageous use of cycled production when insemination, parturition, weaning, and selling etc. are all well organized, thus making it easier to set the work schedule. On a large farm, the entire (empty) rabbitry is cleaned and disinfected. Only pregnant rabbits are housed into cages and all the nest boxes are prepared. During kindling, strict inspection (nest box controlling) helps solve problems such as kindling on wire net or the scattering of newborn rabbits. During this critical period, all does can be easily provided with treatment by dosing combination of water-soluble vitamins into the drinking water, for example.

All the does are inseminated on the same day, and pregnancies can be examined by palpation 11 to 12 days after AI. All the kits are weaned on the same day and the does or kits are moved into another rabbit house. After weaning medicated feed can be used for prevention of some gastrointestinal diseases and coccidiosis. At the end of the fattening period, all the growing rabbits are sent to the slaughter house. On most farms in Europe, does are inseminated 11 days after parturition (in over $90 \%$ of the farms in France, Azard (2006)). This is known as the 42-d reproduction rhythm: pregnancy lasts around $31 \mathrm{~d}+11 \mathrm{~d}$ between kindling and insemination for a total of 42 days. If the rabbits are inseminated on Friday, they will be inseminated again 6 wks later on Friday, and they will always kindle between Monday and Wednesday (31 to 33 days later).

In addition to the 42-d reproduction rhythm (AI 11 days postpartum), 35-, 49- or 56-d rhythms can be adopted. In such cases, does are inseminated 4, 18, or 25 days after parturition.

The 35-d rhythm is too intensive and rarely used in Europe.

In the 42-d rhythm, kits are weaned at 28 to 32 days of age and the growing rabbits are sold at the age of 70 to 74 days. The average weight at this age is from 2.4 to $2.5 \mathrm{~kg}$ (Jentzer, 2008). The $42+42$ day period is enough to empty the building and to clean and disinfect the cages before the next group of rabbits is housed. When the slaughter age approaches 80 to 84 days, there is not enough time for cleaning and the moving of new stock. In this case, a 49-d reproduction rhythm is recommended. The kits can be weaned at the age of 35 to 42 days and the growing rabbits can be transported to the slaughter house at the age of 84 to 86 days.

Comparing the 42- and the 56-d reproduction rhythms, Feugier and Fortun-Lamothe (2006), Xiccato et al. (2005) and Castellini et al. (2006) found no significant differences between the two groups. In a recent experiment (Szendrö et al., 2008) in a 42-d rhythm group, biostimulation (changing nursing method 3 days before $\mathrm{AI}$ ) was applied, and when a 56-d rhythm was adopted, kits were weaned at 23 days of age (two days before AI). Due to the longer time until reinsemination ( $\mathrm{d} 11$ or 25), 56-d rhythm was more favourable (body condition and survival of does) from the animal welfare viewpoint, but number of kits/doe/year of the 42-d group exceeded that of the 56-d rhythm by 19 to $23 \%$ which has a high economic impact on rabbit farm (Gerencsér et al., 2011a)

Hormonal treatment and biostimulation: Lactating does are inseminated by AI. The conception rate depends on their receptivity. Theau-Clément et al. (2006) observed particularly strong antagonism between lactation and reproductive functions in non-receptive does. Hormonal treatment (Pregnant Mare Serum Gonadotrophin - PMSG, or eCG) is recommended for increasing lactating doe receptivity.

The advantages of PMSG treatment are:

- higher doe receptivity rate,

- higher conception rate,

- larger litter size,

- effects are stronger when body conditions are weaker.

PMSG treatment may have some negative effects as well:

- ineffective with non-receptive does,

- increased anti-PMSG antibody rate following frequent and/or high dosage treatment,

- lower conception rate after frequent use,

- higher mortality after birth,

- most of consumers are contrary to the use of hormones in animal production.

The negative effects of PMSG treatment suggest of nonhormonal alternative methods (e.g. biostimulation) (Theau-Clément, 2007). Farms may use three different methods:

- lighting programs,

- short dam-litter separation,

- changing nursing methods.

Lighting program: Wild rabbits start going into heat in the spring when the daylight period gets longer. This marks the beginning of their reproductive period. A similar effect can be created by increasing the daily light period in rabbitries. When daily lighting is extended from 8 to $16 \mathrm{~h}$ around eight days before AI, the conception rate is higher by about 10\% (Theau-Clément et al., 1990; Mirabito et al., 1994; Gerencsér et al., 2008). In a study conducted by Maertens and Luzi (1995a), lighting was increased from 10 to $16 \mathrm{~h} / \mathrm{d}$ five days before AI but no significant change was observed in the conception rate.

Weaned rabbit body weight has decreased in all the following experiments conducted (Theau-Clément et al., 
1990; Mirabito et al., 1994; Maertens and Luzi, 1995a; Gerencsér et al., 2008). It seems that shortening the dark period may have a direct or indirect negative effect on feed intake or/and milk production of does.

Comparing the continuous 16-h light (16 h light:8 h dark - $16 \mathrm{~L}: 8 \mathrm{D})$ with the lighting schedule of $8 \mathrm{~L}: 7 \mathrm{D}: 1 \mathrm{~L}: 8 \mathrm{D}$, the addition one hour lighting period had no favourable effect on production of does (Gerencsér et al., 2011b). Examining the interrupted lighting program of $8 \mathrm{~L}: 4 \mathrm{D}: 8 \mathrm{~L}: 4 \mathrm{D}$, found it had no significant effect on any reproductive traits, but it disturbed the nursing behaviour of does (Gerencsér et al., 2012). Similar results were achieved when the lighting schedule of 12 L:6 D was examined (Matics et al., 2012).

Doe-litter separation (DLS): Most does go into heat shortly after weaning. When milk production ends, the inhibitory effect of prolactin on the ovulatory cycle is diminished.

Does regularly nurse their kits once-a-day (Hudson et al., 2000). If the duration between two nursing events is longer than $24 \mathrm{~h}$, hormonal changes similar to those observed after weaning can be expected, and receptivity increases.

The data summarized by Theau-Clément et al. (2006) indicates that a DLS of $48 \mathrm{~h}$ leads to a better improvement in conception rate than one of 24 to $36 \mathrm{~h}$. In most of the cases using free nursing the kindling rate increased significantly ( 2 out of 5,2 out of 2 and 5 out of 6 experiments by 11,13 and 16 to $24 \%$, respectively, if the duration of DLS was 24, 36 and 48 h) (Theau-Clément, 2006). But the effect of DLS on conception rate was not significant in case of controlled nursing (Theau-Clément, 2006). Although DLS has no effect on litter size, the individual weight of kits at weaning decreases because one suckling event is lost. The effectiveness of DLS was proven in the free nursing system, whereas its effect on controlled nursing groups was insignificant.

Similar results can be achieved if the nursing method is changed. When free nursing is initially applied and then changed to controlled nursing (nest box opened only in the morning for about $20 \mathrm{~min}$ ), the does begin to be excited around midnight (at the former nursing time) (Matics et al., 2004). If the nursing method is changed 2 or 3 days before $\mathrm{AI}$, the receptivity and conception rates are higher by 15 to $27 \%$, and sometimes even the litter size (Theau-Clément, 2006). The separation of does by metal plate or taking the litter with the nest-tray $5 \mathrm{~m}$ away from the doe (permit visual contact or no contact at all) for 3 -d control nursing before AI were more effective than using wire-mesh separation (Eiben et al., 2007).

All three methods are good alternatives to hormonal (PMSG) treatments and are easy to use on farms. Other methods were also investigated but were either ineffective (buck effect, feeding program) or less practical (changing cages, gathering does).

The effectiveness of hormonal treatment or biostimulation methods depends on the basic performance of does. In experiments when the conception rate of the control group was low (50 to $60 \%$ ), all the methods were effective. When the conception rate was 75 to $80 \%$, the difference between the control and treated groups was insignificant. The effectiveness of these methods also depends on the age (parity order) of the does (Maertens, 1988). The differences between the control and treated (PMSG or DLS) groups were highest after the first parturition. In this case, the condition of the primiparous does was weak due to their lower energy deposits (fat) for growing, pregnancy, and lactation. Without treatment, the conception rate might also be low. Subsequently (after the 3rd or 4th litter), there are no significant differences among groups. The weakest does (dead or culling) are eliminated; the condition of the remaining animals is better and they are able to consume more feed than the younger females.

AI has the advantage of spreading high genetic values quickly. When beginning a new rabbit stock, one major risk is that some diseases (e.g. Dermatophytes) can be carried by living animals. The infection of the "old stock" can be minimized by using only sperm.

\section{Suckling mortality}

Increasing the total number of rabbits born is essential to potential reproductive ability. Farmers must also raise the number of animals weaned or sold. One part of reproductive performance is doe nursing ability: what percentage of the newborn rabbits is still alive at weaning? The main factors in pre-weaning mortality are stillborn animals, total litter loss, and suckling mortality.

Examining the effects on total litter loss and suckling mortality, the main reasons are ascribed to birth weight, litter size, and doe age (Szendrö and Barna, 1984). Rossel (2005) examined the reasons of suckling mortality in 167 Spanish rabbit farms and observed $6.3 \%$ stillborn and $13.4 \%$ suckling mortality. Most of the mortality was not based on disease. Compared to total mortality (100\%), 38\% were stillborn, $19 \%$ died of starvation, and $17 \%$ due to hypothermia.

Genotype has a significant effect on total litter loss and suckling mortality (Szendrő et al., 1996). Mortality in inbred stock is higher, but lower in crossbred population. Hamilton et al. (1997) observed 12.4, 10.5 and $8.8 \%$ mortality in Californian, New Zealand and their crossed genotypes, respectively. Some of authors (Baselga et al., 1982; Krogmeier and Dzapo, 1991; Nofal et al., 1995) observed a slight heterosis effect in suckling mortality.

The total litter loss ratio is high in groups of primiparous does (Varga and Szendrö, 1984; Szendrö and Barna, 1984), but it is also high when does spend longer 
than 1.5 years in production. Higher losses in the first litter could be linked to weaker doe condition (body reserves lost during pregnancy, energy expended for growth). The second peak of mortality can be explained by the age of the does. In order to reduce kit mortality, doe condition and health status at the time of mating must be examined.

Mortality is closely linked to litter size. Szendrő and Barna (1984) observed higher total litter loss and suckling mortality in small and large litters, respectively.

Embryonic mortality is higher in animals that are too young, too old or sick, and in rabbits with weak condition. These rabbits also have poor litter rearing ability. PMSG is commonly used for receptivity synchronisation in Europe despite hormonal treatment's side-effects (Maertens and Luzi, 1995b). Some does with low condition or weak health status may kindle mostly small litters with higher total litter loss. Superovulation is also sometimes seen: the kindling of large litters with some low birthweight kits and as a consequence the viability of kits also decreases.

Rabbit mortality can be decreased by fostering. Successful fostering is closely linked to equalizing not only the number but also weights within the litter. Poigner et al. (1999) created different litters by cross-fostering. In Experiment No. 1, litters with 6, 8 and 10 kits were heterogeneous (there were small, medium and large-bodied newborn rabbits in each litter). In Experiment No. 2, similar-sized litters $(6,8$ or 10 kits/litter) were formed but only small, medium or large-sized kits were within the homogeneous litters. A comparison of suckling mortality showed mortality to be significantly lower in the homogenous litters with 10 kits than in Experiment No. 1.

The aim of fostering is to give all the rabbits in the litter the same chance to suck. When they can consume more milk, their viability is higher. Kits nursed by two does also offers better survival probability (Gyovai et al., 2004a). Not only total (daily) milk production is important. Coureaud et al. (2000) observed a close connection between immediate postnatal suckling and kit survival. Similar results were published by Farougou et al. (2006).

Nursing method also affects suckling mortality. Szendrő et al. (1999) compared suckling methods (free = nest box open for $24 \mathrm{~h}$, controlled $=$ nest box closed and opened only in the morning for half an hour, combined = free nursing in first week and controlled afterwards). Controlled nursing provided the best results for primiparous does, whereas free nursing seemed to work best for multiparous females. The mortality was 12.2 and $6.3 \%$ (free nursing) and 6.4 and $11.4 \%$ (controlled nursing), respectively in groups primiparous and multiparous does.

\section{Teat number}

Teat numbers on rabbits are most frequently 8,9 or 10 .
Teat number distribution varies by genotype. The frequency of rabbits with 8 teats was between 23 and $70 \%$ and that of 10 teats between 13 and $50 \%$ depending on the genotypes (Szendrő et al., 1984; Rochambeau et al., 1988; Virág et al., 1991).

The number of doe teats and reproductive ability are in positive correlation. In a previous study (Szendrő and Holdas, 1984), rabbits with 10 teats kindled higher numbers of kits (5 to $10 \%$ more than does with 8 teats). Although rabbits with higher numbers of teats do not produce more milk due to the fact that mammary gland size does not dependent on teat number, does with more teats have better nursing ability. Comparisons of groups of does with 8 and 10 teats showed the difference in kit mortality to be around 5 to $7 \%$ and to vary from one stock to another.

Nursing time duration runs from 2.5 to 3 min (Hudson et al., 2000; Matics et al., 2004). During this short period, kits are able to suck an amount of milk equal to 15 to $20 \%$ of their body weight. Kits suck very strongly. The moment they feel the teat empty, they release it and try to catch another one. Their chances here depend on teat number and litter size. In a 10-kit litter, two kits are waiting for a teat every second if the doe's teat number is only 8 . With 10 teats, all the kits have the opportunity to consume milk.

The effect of teat number on suckling mortality is more remarkable in large litters. In an experiment by Rochambeau et al. (1988), the average number of rabbits born alive was 11.78 . The mortality until weaning in groups of does with 8,9 or 10 teats was $2.97,2.03$ and 1.75 kits/litter. When selecting breeding animals, breeders give preference to rabbits with 10 teats. The question is which age is the best for selection. Rabbits are born furless. After suckling, with the stomach full of milk and the skin unwrinkled, it is easy to count the teats in good light. Kits with 10 teats can be marked (e.g. on their ears) to display their teat number when the body is later covered with fur.

Not only female but male rabbits must be selected. Teat number heritability in rabbits is high (Szendrő et al., 1991). The distribution of progenies with $7,8,9,10$ and 11 teats differs significantly when crossing parents with 8 or 10 teats. The percentage of kits with 10 teats increases with the average number of teats on their parents. Crossing the rabbits with 8 or 10 teats the percentage of progenies with 10 teats were 53 and 14 , respectively.

The effectiveness of selection was proven by Virág et al. (1991), who were able to improve the ratio of rabbits with 10 teats and the average number of teats after a 2-year selection. There is a significant correlation between teat number and litter size (Szendrö and Holdas, 1984). Whenever we select by teat number, doe performance improves. Vice-versa, Rochambeau et al. (1988) compared the teat numbers of non-selected and selected lines in terms 
of litter size. The higher teat number was observed in the latter group.

\section{Seasonal effect}

In continental climate countries daylight and temperatures vary considerably around the year and therefore the seasonal effect on reproductive and productive performance is important. In natural habitats rabbit reproduction is strongly influenced by the season, and stops from late autumn until early spring. The reason for this is the shorter daylight period.

On small and medium farms, the receptivity and the conception rates are higher in spring because the daylight period is longer. A lower number of kits is born in summer due to the higher embryonic mortality caused by high temperature. Hot climate leads to lower feed consumption and consequently lower milk production and higher suckling mortality. As temperatures rise, rabbits can only accelerate heat release by vasodilatation to increase blood flow, and increase breath frequency (Yingkai and Mingrong, 2008). In autumn, the receptivity may be lower (Csonkáné and Szendrö, 1984) primarily due to the moulting caused by shortening of daylight period. In winter, low temperatures of even -10 or $-20^{\circ} \mathrm{C}$ sometimes cause problems in some countries.

Effect of hot climate can be reduced by keeping rabbits on wire net floors or shearing hair from animal backs and sides help eliminate heat (Szendrő et al., 2007b). In winter, more straw in the cage and better covered (insulated) cages create a slightly warmer climate.

In buildings with continuous 16-h lighting all year round, the varying daylight effect is negligible. Sprinkling water on the floor (for higher humidity) and cooling the building are good ways to decrease the extreme temperature effect.

Cooling and heating systems are used mainly at large farms. Ventilation is one form of building climate control; effectiveness depends on the difference in relative humidity outside and inside the building. Ventilation can decrease building temperature remarkably. The advantage offered by forced-air cooling is that it also blows out animal heat and environmental humidity (Yingkai and Mingrong, 2008). Good environmental conditions are essential for better reproductive and productive performance.

\section{CONCLUSIONS}

It is difficult to formulate a complete reproduction management strategy. The objective of improving doe reproductive performance must take the following points of greater or lesser importance into account. A summary of this paper's results has produced the recommendations below:

- The breed must be chosen by considering the conditions at the farm (native or other coloured breeds should be used under lower level conditions; intensive breeds and hybrids can be used when higher standards are present).

- Crossbreeding leads to heterosis in reproductive performance.

- The selection of the best does should start at birth. Choosing kits from large litters with birth weight higher than or closest to the average with 10 (or a minimum 9) teats is advantageous.

- After weaning, either restricted feeding or high fibre diets are suggested for future does until 6 to 8 days before first mating.

- Genetics, housing, and feeding levels must be suited to the re-mating interval.

- Mating does twice immediately one after the other gives the best results.

- Using artificial insemination and 42- or 49-d reproductive rhythms are suggested for large farms. High levels and frequent use of PMSG treatment must be avoided. Biostimulation methods (dam-litter separation, changing nursing methods, and lighting programs) are all good alternatives to hormonal treatment.

- Fostering is suggested to form balanced (homogeneous) litters in terms of size and birth weight. - Controlled nursing is advised for primiparous does; free nursing is recommended for multiparous does

- The seasonal effect on reproductive performance can be reduced by continuous 16-h lighting, cooling and heating depending on the climate.

\section{REFERENCES}

Azard, A. 2006. Caractérisation des systémes de production cunicole francais et perspectives d'évolution. Cuniculture Magazine 33:78-85. (in French)

Babilé, R., M. Cabdau, A. Auvergne and R. Fhari. 1982. Effets de l'environnement post natal sur la reproduction des lapines. Premiers resultats. Proc. $3^{\text {émes }}$ Journ. Rech. Cunicole, Paris, France, Comm. 30. (in French)

Barker, D. J. P., C. Osmond, J. Golding, D. Kuh and M. E. J. Wadsworth. 1989. Growth in utero, blood pressure in childhold and adult life, and mortality from cardiovascular disease. Br. Med. J. 298:564-567.

Baselga, M., A. Blasco and F. Garcia. 1982. Parametros geneticos de caracteres en poblaciones de conejos. Proc. 2nd World Congr. Gen. Appl. Liv. Prod., Madrid, Spain, pp. 471-480.

Beyer, C. and N. Rivaud. 1969. Sexual behaviour in pregnant and lactating domestic rabbits. Physiol. Behav. 4:753-757.

Brun, J. M. and M. Baselga. 2005. Analysis of reproductive performances during the formation of a synthetic rabbit strain. World Rabbit Sci. 13:239-252.

Brun, J. M. and G. Saleil. 1994. Une estimation, en fermes, de l'heterosis sur les performances de reproduction entre les 
souches de la lapin IRA A 2066 et A1077. Proc. $6^{\text {émes }}$ Journ. Rech. Cunicole, La Rochelle, France, pp. 203-210. (in French)

Brun, J. M., G. Bolet and J. Ouhayoun. 1992. The effect of crossbreeding and reproductive traits in triallel experiment between three strains of rabbits. Proc. 5th World Rabbit Congress, Corvallis, USA, Vol. A, pp. 181-189.

Brun, J. M., G. Bolet, M. Baselga, J. Esperabil and J. Falieres. 1998. Comparaison de deux souches européennes de lapins sélectionées la taille de porté: intéret de leur croisement. Proc $7^{\text {émes }}$ Journ. Rech. Cunicole, Lyon, France, pp. 21-23. (in French)

Castellini, C., A. Dal Bosco and R. Cardinali. 2006. Long term effect of post-weaning rhythm on the body fat and performance of rabbit doe. Reprod. Nutr. Dev. 46:195-204.

Cheeke, P. R., N. M. Patton, S. D. Lukefahr and J. I. McNitt. 1986. The rabbit production. The Interstate Printers\&Publ., Danville, Illions, USA

Coureaud, G., B. Schaal, P. Coudert, P. Rideaud, L. FortunLamothe, R. Hudson and P. Orgeur. 2000. Immediate postnatal suckling in the rabbit: Its influence on pup survival and growth. Reprod. Nutr. Dev. 40:19-32.

Csonkáné and Zs. Szendrő. 1984. Effect of season on productive traits of rabbits. Reports Res. Centre Anim. Proc. Nutr., Gödöllö, Hungary, pp. 323-329.

Das, S., N. Ghosh and S. K. Ray. 1997. Reproductive performance of broiler rabbits (Oryctolagus cuniculus) in West Bengal. Indian Anim. Sci. 67:314-315.

Di Meo, C., S. Bovera, S. Marono, N. Vella and A. Nizza. 2007. Effect of feed restriction or performance and feed digestibility in rabbits. Ital. J. Anim. Sci. 6:765-767.

Doblhammer, G. and J. W. Vaupel. 2001. Lifespan depends on month of birth. Proc. Natl. Acad. Sci. 98:2934-2939.

Eiben, Cs., K. Kustos, Á. Kenessey, Gy. Virág and Zs. Szendrő. 2001. Effect of different feed restriction during rearing on production performance in rabbit does. World Rabbit Sci. 9:914.

Eiben, Cs., G. Tóbiás, K. Kustos, K. Gódor-Surmann, Sz. Kotány, B. Gulyás and G. Szira. 2007. The change of nursing for oestrus induction (biostimulation): Effect of contact between rabbit doe and its young. Livest. Sci. 11:193-203.

Farougou, S., M. Kpodékon, B. Koutinhouin, O. D. H. Brahi, Y. Djago, F. Lebas and P. Coudert. 2006. Impact of immediate postnatal suckling on mortality and growth of sucklings in field condition. World Rabbit Sci. 14:167-173.

Feugier, A. and L. Fortun-Lamothe. 2006. Extensive reproductive rhythm and early weaning improve body condition and fertility of rabbit does. Anim. Res. 55:459-470.

Garreau, H., M. Piles, C. Larzul, M. Baselga and H. Rochambeau. 2004. Selection of maternal lines: last results and prospects. Proc. 8th World Rabbit Congress, Puebla City, Mexico, pp. 1425.

Gerencsér, Zs., Zs. Matics, I. Nagy, Z. Princz, Z. Orova, E. BíróNémeth, I. Radnai and Zs. Szendrő. 2008. Effect of light stimulation on the reproductive performance of rabbit does. Proc. 9th World Rabbit Congress, Verona, Italy, pp. 371-374.

Gerencsér, Zs., Zs. Matics, I. Nagy and Zs. Szendrö. 2011a. Effect of light colour and reproductive rhythm on rabbit doe production. World Rabbit Sci. 19:161-170.
Gerencsér, Zs., Zs. Matics, I. Nagy, I. Radnai, É. Szendrő and Zs. Szendrő. 2011b. Effect of lighting schedule on production of rabbit does. World Rabbit Sci. 19:209-216.

Gerencsér, Zs., Zs. Matics, I. Nagy, I. Radnai, É. Szendrő and Zs. Szendrö. 2012. Effect of lighting program and nursing method on the production and nursing behaviour of rabbit does. World Rabbit Sci. (in press)

Gondret, F., F. Lebas and M. Bonneau. 2000. Restricted feed intake during fattening reduces intramuscular lipid deposition without modifying muscle fiber characteristics in rabbits. J. Nutr. 130:228-233.

Gyovai, M. 2006. Effects of nutrient supply during rearing and age at first insemination on the performance of rabbit does. $\mathrm{PhD}$ thesis, University of Kaposvár, Hungary.

Gyovai, M., L. Maertens, I. Nagy, E. Biró-Németh, I. Radnai, Z. Princz, Zs. Gerencsér and Zs. Szendrö. 2004a. Examination of factors influencing rabbit survival (preliminary results). Proc. 8th World Rabbit Congress. Puebla City, Mexico, pp. 11281133.

Gyovai, M., Zs. Szendrő, L. Maertens, E. Biró-Németh, I. Radnai, Zs. Matics, Zs. Gerencsér, Z. Princz and P. Horn. 2004b. Effect of the rearing method on the performance of rabbit does. Proc. 8th World Rabbit Congress, Puebla City, Mexico, pp. 281-286.

Hamilton, H. H., S. D. Lukefahr and J. I. McNitt. 1997. Maternal nest quality and its influence on litter survival and weaning performance in commercial rabbits. J. Anim. Sci. 75:926-933.

Hartmann, J. and J. Petersen 1997. Körpergewichtsentwicklung und Milchleistung in den ersten drei Wochen der Laktation in Abhängigkeit von Hybridhäsinnen. 10. Arbeitstagung über Haltung und Krankheiten der Kaninchen, Pelztiere und Heimtiere, Celle, Germany, pp. 24-32. (in German)

Hudson, R., B. Schaal, M. Martínez-Gómez and H. Distel. 2000. Mother-young relations in the European rabbit: Physiological and behavioural locks and keys. World Rabbit Sci. 8:85-90.

Jensen, N. E., J. F. Jensen, Zs. Szendrő and P. Sorensen. 1996. Diallel crossbreeding experiment in Danish and Hungarian meat rabbits. 1. Reproductive performance, growth and feed conservation. World Rabbit Sci. 4:109-114.

Jentzer, A. 2008. Performances moyennes des élevages cunicoles en 2007. Présentation rapide des résultats RENACEB et RENALAP. Cuniculture Magazine, 35:39-44.

Khalil, M. H. and A. M. Al-Saef. 2008. Methods, criteria, techniques and genetic responses for rabbit selection: A review. Proc. 9th World Rabbit Congress, Verona, Italy, pp. 1-22.

Khalil, M. H., E. A. Afifi, A. Farid and Y. K. Youssef. 2002. Estimation of crossbreeding effects for some litter traits in crossing of New Zealand White with Egyptian Galabi rabbits. Egypt Rabbit Sci. 12:143-153.

Krogmeier, D. and V. Dzapo. 1991. Leistungmerkmale von Kaninchen der Rassen Weisse Nenseeländer, Halle Grossilber sowie deren reciproker Krenzungen. Arch. Geflügelk. 55:158162. (in German)

Langley-Evans, S. C. and D. V. Sculley. 2006. The association between birthweight and longevity in the rat is complex and modulated by maternal protein intake during fetal life. FEBS Lett. 580:4150-4153.

Lebas, F. 1982. Influence de la position in utero sur le développement corporel des laperaux. $3^{\text {émes }}$ Journées de la 
Recherche Cunicule, Paris, France (in French)

Lebas, F., P. Coudert, R. Rouvier and H. de Rochembau. 1986. The rabbit husbandry, health and production. FAO Animal Production and Health Series, no. 21, Rome, Available online at: http://www.fao.org/docrep/X5082E/X5082E00.htm

Lukefahr, S. D. 1992. The rabbit project manual. A trainer manual for meat rabbit project development. Heifer Project International, Little Rock, USA.

Hanzhong, L. 2008. Survey report for present situation of technology system of China rabbit industry - national survey group for technology system of rabbit industry. Proc. 9th World Rabbit Congress, Verona, Italy, pp. 1565-1569.

Maertens, L. 1998. Effect of flushing, mother-litter separation and PMSG on the fertility of lactating does and the performance of their litter. World Rabbit Sci. 6:185-190.

Maertens, L. and F. Luzi. 1995a. Effect of diluent and storage time of rabbit semen on the fertility of does reared under two different lighting schedule. World Rabbit Sci. 3:27-34.

Maertens, L. and F. Luzi. 1995b. Note concerning the effect of PMSG stimulation on the mortality rate at birth and the distribution of litter size in artificially inseminated does. World Rabbit Sci. 3:57-61.

Maertens, L., F. Okerman, G. De Groote and R. Moermans. 1983. L'incidence de deux méthodes de traitement hormonal sur le comporment sexuel et la fertilité de jeunes lapines. Rev. Agric. 36:167-175.

Masoro, E. J., H. A. Bertrand and F. T. Lynd. 1980. Nutritional probe of aging process. Fed. Proc. 39:3178-3182.

Matics, Zs., Zs. Szendrő, St. Hoy, I. Nagy, I. Radnai, E. BiróNémeth and M. Gyovai. 2004. Effect of different management methods on the nursing behaviour of rabbits. World Rabbit Sci. 12:95-108.

Matics, Zs., I. Nagy, E. Bíró-Németh, I. Radnai, Zs. Gerencsér, Z. Princz and Zs. Szendrö. 2008. Effect of feeding regime during rearing and age at first mating on the reproductive performance of rabbit does. Proc. 9th World Rabbit Congress, Verona, Italy, pp. 399-403.

Matics, Zs., Zs. Gerencsér, I. Radnai, A. Mikó, I. Nagy and Zs. Szendrö. 2012. Effect of different lighting schedules (16 L:8 D or $12 \mathrm{~L}: 6 \mathrm{D})$ on reproductive performance of rabbit does. Proc. 10th World Rabbit Congress, Sharm El-Sheikh, Egypt (in press)

Mirabito, L., P. Galliot and C. Souchet. 1994. Effet de l'utilisation de la PMSG et la modification de la photopériode sur be les performances de production de la lapine. Proc. $6^{\text {émes }}$ Journ. Res. Cunicole, La Rochelle, France, 1, pp. 169-178.

Nizza, A., C. Di Meo and L. Esposito. 1997. Influence of the diet used before and after the first mating on reproductive performance of rabbit does. World Rabbit Sci. 5:107-110.

Nofal, R. Y., S. Tóth and Gy. Virág. 1995. Effects of crossbreeding on some reproductive traits. Állattenyésztés és Takarmányozás, 44:243-248.

Nofal, R. Y., S. Tóth and Gy. Virág. 1996. Evaluation of seven breed groups for litter traits. Proc. 6th World Rabbit Congress, Toulouse, France, pp. 335-339.

Pálos, J., Zs. Szendrö and K. Kustos 1996. The effect of number and position of foetuses in uterine horns on their weight at 30 days of pregnancy. Proc. 6th World Rabbit Congress, Toulouse,
France, Vol. 2, pp. 97-102.

Pascual, J. J., C. Cervera and J. Fernandez-Carmona. 2002. A feeding programme for young rabbit does based on lucerne. World Rabbit Sci. 10:7-13.

Poigner, J., Zs. Szendrő, A. Lévai, I. Radnai and E. Bíró-Németh. 1999. Effect of birth weight and litter size on growth and mortality in rabbits. World Rabbit Sci. 8:17-22.

Poigner, J., Zs. Szendrő, A. Lévai, E. Bíró-Németh and I. Radnai. 2000. Weight of new-born rabbits in relation to their number and position within the uterus in unilaterally ovariectomised does. World Rabbit Sci. 8:231-237.

Pond, W. G. and J. F. Wu. 1981. Mature body weight and life span of male and female progeny of primiparous rats fed a low protein or adequate diet throughout pregnancy. J. Nutr. 111: 1949-1954.

Rochambeau, H. de, F. Tudela and J. Chabert. 1988. Some results about number of teats in 3 strains of rabbits. Proc. 4th World Rabbit Congress, Budapest, Hungary, pp. 261-268.

Rommers, J. M., B. Kemp, R. Meijerhof and J. P. T. M. Noordhuizen. 2001. The effect of litter size before weaning on subsequent body development, feed intake, and reproductive performance of young rabbit does. J. Anim. Sci. 79:1973-1982.

Rossel, J. M. 2005. The suckling rabbit: health, care and survival. A field study in Spain and Portugal during 2003-2004. Proc. 4th Int. Conf. Rabbit Prod. Hot Climates, Sharm-El-Sheik, Egypt, pp. 1-9.

Szendrö, Zs. and J. Barna. 1984. Some factors affecting mortality of suckling and growing rabbits. Proc. 3rd World Rabbit Congress, Roma, Italy, pp. 166-173.

Szendrö, Zs. and S. Holdas. 1984. Relationship between the number of teat and the production of female rabbirts. Proc. 3rd World Rabbit Congress, Rome, Italy, 11, pp. 141-148.

Szendrő, Zs. and L. Maertens. 2001. Maternal effect during pregnancy and lactation in rabbits. Acta Agric. Kapos. 5:1-21.

Szendrő, Zs. and H. Tag-El-Den. 1987. Effect of double mating on the conceptional rate and litter size of rabbit (in Hung.). Magy. Állatorvosok Lapja 42:371-374.

Szendrő, Zs., M. Láng and J. Szabó. 1989. Performance of does in dependence of litter size in which they were born. (in Hung.) Állattenyésztés és Takarmányozás 38:159-164.

Szendrő, Zs., M. M. A. Mohamed and E. Bíró-Németh. 1991. Teat number of new-born rabbits depending on the teat number of their parents. J. Appl. Rabbit Res. 14:133-135.

Szendrő, Zs., E. Biró-Németh, I. Radnai, N. E. Jensen and Á. Kenessey. 1996. The performance of Danish White and Pannon White purebred and reciprocal crossbred rabbits. Proc. 6th World Rabbit Congress, Toulouse, France, Vol. 2, pp. 359364.

Szendrő, Zs., T. Gyarmati, A. Lévai, I. Radnai and E. Biró-Németh. 1999. Comparison of once-daily, free and combined forms of suckling in rabbits. Acta Agric. Kapos. 3:155-163.

Szendrő, Zs., M. Gyovai, L. Maertens, E. Biróné Németh, I. Radnai, Zs. Matics and I. Nagy. 2006a. Effect of rearing method on the lifetime production of does. Proc. 18th Hung. Conf. Rabbit Prod., Kaposvár, Hungary, pp. 117-121.

Szendrő, Zs., A. A. Rashwan, E. Bíró-Németh and I. Radnai. 2006b. Effect of vulva colour and turgidity on conception rate and litter size of rabbit does. Proc. 18th Hung. Conf. Rabbit 
Prod., Kaposvár, Hungary, pp. 123-126.

Szendrő, Zs., K. Kustos, Zs. Juhász, I. Radnai, E. Biró-Németh, Z. Princz, Zs. Matics, P. Gyovai and I. Nagy. 2007a. Effect of crossbreeding on reproductive performance in rabbits. Proc. 19th Hung. Conf. Rabbit. Prod., Kaposvár, Hungary, pp. 65-69. Szendrő, Zs., A. A. Rashwan, E. Bíró-Németh, I. Radnai and Z. Orova. 2007b. Effect of shearing of hair in summer on productioin of rabbit does. Acta Agric. Kapos. 11:37-42.

Szendrő, Zs., Zs. Gerencsér, Zs. Matics, E. Bíró-Németh and I. Nagy. 2008. Comparison of two reproductive rhythms of rabbit does. Proc. 9th World Rabbit Congress, Verona, Italy, pp. 455458.

Theau-Clément, M. 2007. Preparation of the rabbit doe to insemination: a review. World Rabbits Sci. 15:61-80.

Theau-Clément, M., B. Poujardieu and J. Bellerand. 1990. Influence des traitments lumineux, modes de reproduction et états physiologiques sur la productivité de lapines multipares. Proc. $5^{\text {émes }}$ Journ. Rech. Cunicole, Paris, France, Tome 1, Comm. 7.

Theau-Clément, M., C. Boiti, A. Bonanno, Cs. Eiben, L. Maertens and Zs. Szendrö. 2006. Alternative methods for synchronisation of oestrus in lactating rabbit does (Ed. L. Maertens and P. Coudert). Recent advances in rabbit sciences. ILVO, Melle, Belgium, pp. 21-37.
Varga, L. and Zs. Szendrő. 1984. Production of female rabbits as a function of age. Proc. 3rd World Rabbit Congress, Roma, Italy, pp. 87-95.

Virág, Gy., K. Kustos and A. Suschka. 1991. Selection for teat number on a New Zealand population. Proc. 3rd Hung. Conf. Rabbit Prod., Kaposvár, Hungary, pp. 105-113.

Xiccato, G., M. Gernardini, C. Castellini, A. Dalle Zotte, P. Quenaque and A. Trocino. 1999. Effect of postnatal feeding on the performance and energy balance of female rabbits at differint physiological status. J. Anim. Sci. 77:416-426.

Xiccato, G., A. Trocino, C. Boiti and G. Brecchia. 2005. Reproductive rhythm and litter weaning age as they affect rabbit does performance and body energy balance. Anim. Sci. 81:289-296.

Yingkai, Y. and L. Mingrong. 2008. Feeding management and technology of breeding rabbit in hot climate. Workshop Organic farming based on forages, Cantho City, Vietnam. Available online at: http://www.mekarn.org/prorab/content.htm Zhiqiang, L. and C. Xiaoyan. 2008. Rabbit resources of China. Intern. Workshop Organic farming based on forages, Cantho City, Vietnam. Available online at: http://www.mekarn.org/ prorab/content.htm 